\title{
Las élites capitulares indianas y sus mecanismos de poder en el siglo XVII
}

\author{
Manuela Cristina García Bernal \\ Departamento de Historia de América \\ Facultad de Geografía e Historia \\ Universidad de Sevilla
}

\begin{abstract}
El propósito de este trabajo es analizar los diferentes comportamientos de las élites capitulares indianas en el siglo XVII, a fin de establecer en qué medida los cabildos fueron, a través de ellas, instrumentos de las oligarquías para defender sus intereses a nivel local $e$, incluso, provincial, y cuáles fueron los mecanismos de que éstas se valieron para afianzar su poder. Se parte para ello del principio de que en la actuación de las élites capitulares indianas como grupos de poder el proceso fue de la unidad dentro de la diversidad, en la medida en que fueron muy similares los mecanismos de que se valieron para controlar las diferentes esferas de poder. Unos mecanismos, como el sistema de venta y renunciación de los oficios capitulares no electivos impuesto en 1606, las alianzas matrimoniales y las prácticas endogámicas, que dichas élites aplicaron en la mayor parte de los territorios indianos para consolidar su posición y adquirir cohesión y poder.
\end{abstract}

No cabe duda de que en la América hispana la ciudad actuó como instrumento específico de dominación. De ahí la especial trascendencia que la institución del cabildo tuvo en el proceso colonizador de las Indias. Los gobiernos municipales no sólo contribuyeron al arraigo de los cientos de villas y ciudades que surgieron al socaire del avance español, sino que se convirtieron en las piezas claves para el desarrollo de la vida urbana en los nuevos territorios. Es más, al constituir el principal órgano de expresión de los colonizadores y de sus intereses, acabaron por ser la imagen exacta de la realidad social prevaleciente en sus respectivas jurisdicciones. Quizá por ello el análisis de los cabildos permite entender los comportamientos de las oligarquías indianas y, más concretamente, de las élites capitulares.

Ahora bien, a la hora de profundizar en la historia de los concejos indianos no se debe olvidar la vital importancia que en la misma tuvo el siglo XVII. Es cierto que en un principio el municipio indiano, como heredero del viejo municipio castellano medieval, consiguió recuperar su per-

* Una versión preliminar de este trabajo fue presentada en el Seminario sobre El municipio castellano y su comparación con el municipio indiano, organizado en Valladolid por la Fundación Duques de Soria dentro del marco de la Cátedra "Luis Ga de Valdeavellano" (27 y 28 de octubre de 1998). 
dida vitalidad y relieve político, al convertirse su cabildo en un poderoso representante de los intereses de lo que podría considerarse estado llano. Pero también lo es que pronto se vería truncada esta etapa de aparente florecimiento por la controvertida política de la monarquía reinante, iniciándose así un nuevo período de decadencia al perder los concejos municipales ese carácter de representatividad de los intereses generales que los había caracterizado. ${ }^{1} \mathrm{Y}$ en este sentido no cabe duda de que el siglo XVII, que tan decisivo fue para el afianzamiento de las instituciones americanas y para la profunda transformación de la sociedad indiana, se revela como un período cronológico fundamental para la evolución de los cabildos indianos, al ser éstos una de las instituciones que más acusaría los efectos de la política de los Austrias.

A este respecto, basta con recordar que fue a principios de la centuria cuando culminó un proceso de enajenación de oficios públicos que se había iniciado en 1559. Efectivamente, fue en 1606 cuando se instauró un verdadero sistema, coherente y completo, de venta y renunciación perpetua de la mayoría de los oficios indianos, algo que no tenía precendente en el modelo legal castellano, donde no se reconocía la calidad de perpetuamente renunciables a los oficios ya vendidos o vendibles. De ahí que Tomás y Valiente asentara que el nuevo régimen sobre ventas de oficios "significó la emancipación del Derecho indiano respecto al de Castilla". ${ }^{2}$ Ni que decir tiene que la cédula de 1606, que implantaba dicho sistema, fue de enorme importancia para la vida municipal indiana, pues con ella se inició una nueva etapa en la historia de los cabildos coloniales, toda vez que se modificó sustancialmente la forma de acceder a los mismos y con ello se determinó también su estructura y composición socioeconómica. Es evidente que la nueva disposición favoreció de forma definitiva el que al frente de los gobiernos municipales se impusieran las oligarquías locales que, gracias a sus recursos económicos, se encontraron en situación de ejercer el control de los mismos a través de generaciones, propiciándose así el establecimien-

1 Ots Capdequí, José María: "El régimen municipal hispanoamericano del período colonial", Tierra Firme, núms. 3-4, Valencia, 1937, págs. 353-354, e Historia del Derecho español en América y del Derecho indiano, Madrid, 1969, págs. 143-144.-Bayle, Constantino, Los cabildos seculares en la América española, Madrid, 1952, págs. 15-39.—Ramos, Demetrio, "Los cabildos señoriales de la época de Diego Colón”, Revista de Historia del Derecho, núm. 5, Buenos Aires, 1977, págs. 235, 238 y $242-243$.

2 Parry, J.H.: The sale of public office in the Spanish Indies under the Hapsburgs, Berkeley and Los Angeles, 1953, págs. 12-18, 32-33 y 42; Tomás y Valiente, Francisco: La venta de oficios en Indias (1492-1606), Madrid, 1972, págs. 61-71, 76-93, 121-133 y 138 (la cita textual corresponde a la página 124); Avellá Vives, Joaquín: Los cabildos coloniales, Madrid, 1934, págs. 163-165. 
to de dinastías familiares que pudieron, incluso, reforzar su poder mediante la presencia simultánea de varios miembros de la familia. Al mismo tiempo, la enajenación en subasta pública de los oficios capitulares supuso en muchos cabildos el desplazamiento de los encomenderos o beneméritos y su sustitución por los nuevos grupos emergentes de hacendados, estancieros, mercaderes o mineros, en cuanto que éstos disponían de la riqueza necesaria para adquirir los oficios capitulares que el nuevo régimen les brindaba. En otros concejos, sin embargo, lo que hizo el nuevo sistema fue más bien facilitar la integración de estos grupos dentro de los círculos dominantes, sobre todo en aquellas regiones, como Yucatán o Chile, donde existían unas élites de carácter aristocrático, fuertemente cohesionadas y poderosas, y donde el prestigio social que conferían los oficios capitulares se convirtió en un claro vehículo de promoción social. De todas formas, lo que sí parece claro es que el sistema impuesto en 1606 puso en manos de las oligarquías indianas los medios necesarios para aumentar su influencia y participación política en la vida ciudadana.

Nuestro propósito es, por tanto, analizar los diferentes comportamientos de las élites capitulares indianas en el siglo XVII, a fin de establecer en qué medida los cabildos fueron, a través de ellas, instrumentos de las oligarquías para defender sus intereses a nivel local e, incluso, provincial, y cuáles fueron los mecanismos de que éstas se valieron para afianzar su poder.

No obstante, partimos del hecho de que la estructura y la composición de los cabildos estuvieron en gran medida condicionadas por el ámbito geo-económico en que estaban inmersos. Lo cual no es nada extraño si se considera que la diversidad era, y sigue siendo, la principal característica de los territorios americanos. Una diversidad que se impuso desde el primer momento, como lo testimonia la misma casuística de la legislación indiana, y que también afloró en la propia estructura interna de los cabildos. Y es que cada vez se hace más evidente que los cabildos no fueron instituciones de patrón fijo, sentenciadas a reproducir los mismos esquemas orgánicos en todas las regiones, sino "entes vivos", en cuanto que tuvieron libertad para fijar algunos de sus cargos e, incluso, definir sus competencias y privilegios. Es decir, aun teniendo que respetar un núcleo integrado por los alcaldes ordinarios, los regidores y el escribano, junto con unas normas básicas comunes a todos, los gobiernos locales que se establecieron en Indias no estaban obligados a instituir un esquema global prefijado, lo que permitió que cada cabildo pudiera diseñar su propia estructura en función de las particulares características de su territorio. Así lo ha podido verificar 
González Muñoz, para quien esta "diversidad dentro de la unidad" se hace patente en el hecho de que los tres ayuntamientos de Yucatán, aun perteneciendo a la misma gobernación, presentaran un perfil distinto y peculiar, con claros matices diferenciadores, lo que avala con toda nitidez su tesis de que en Indias ningún cabildo fue exactamente igual a otro. ${ }^{3}$

Ciertamente, nuestro tema no es el análisis institucional. Pero no ignoramos la importancia que tiene el conocimiento de la estructura y funcionamiento interno de los cabildos tanto para entender la cotización y el atractivo de los oficios capitulares en función de sus competencias y prerrogativas, como para valorar su proyección en sus respectivos municipios. Por ello sí interesa resaltar que, gracias a los estudios regionales que se han hecho, el cabildo indiano comienza a dar la imagen de una institución dúctil, adaptada a su zona y, por tanto, con personalidad propia. ${ }^{4}$ Lo cual, por otra parte, no es extraño, si se tiene en cuenta que no hubo una sociedad indiana, sino muchas sociedades indianas, y que los concejos no hicieron sino reflejar fielmente la sociedad en que se encontraban insertos. De ahí su diversidad y también su importancia para entrever las glorias y tensiones de los diferentes núcleos urbanos, pues no en vano las élites capitulares, a pesar de su reducido número, constituyeron cabal representación de un amplio tejido social que en no pocos casos trascendía los límites del municipio que administraban para llegar a revelar la idiosincrasia de la región.

3 González Muñoz, Victoria: Cabildos y grupos de poder en Yucatán (siglo XVII), Sevilla, 1994, págs. 25-26 y 289-290.

4 Alemparte, Julio: El cabildo en Chile colonial, $2^{\mathrm{a}}$ ed. Santiago de Chile, 1966; Moore, John Preston: The Cabildo in Perú under the Hapsburgs, Durham, N.C., 1954; Zorraquín Becú, Ricardo: "Los cabildos argentinos", Revista de la Facultad de Derecho y Ciencias Sociales, año XI, núm. 47, Buenos Aires, 1956, págs. 95-156; Zuluaga, Rosa M.: El Cabildo de la ciudad de Mendoza. Su primer medio siglo de existencia, Mendoza, 1964; Arcaya U., Pedro M.: El cabildo en Caracas, Caracas, 1965; Liehr, Reinard: "Ayuntamiento y oligarquía de la ciudad de Puebla a fines de la colonia (1787-1810)", Jahrbuch für Geschichte von Staat, Wirtschaft und Gesellschaft Lateinamerikas, núm. 7, Köln, 1970, págs. 417-426; Nava Otero, Guadalupe: Cabildos y ayuntamientos de la Nueva España en 1808, México, 1973; Doucet, Gastón: "Feudatarios y soldados en el cabildo de Córdoba", Revista de Historia del Derecho, núm. 2, Buenos Aires, 1974, págs. 383-406; Muñoz, Virgilio y Mario Ruiz-Massieu: Elementos jurídico-históricos del municipio en México, México, 1979; Peña, José F. de la y Ma Teresa López Díaz: "Comercio y poder. Los mercaderes y el cabildo de Guatemala, 1592-1623”, Historia Mexicana, vol. XXX, núm. 4, México, abril-junio 1981, págs. 469-505; Webre, Stephen: "El cabildo de Santiago de Guatemala en el siglo XVII: ¿una oligarquía criolla cerrada y hereditaria?, Mesoamérica, núm 2, Guatemala/Vermont, junio 1981, págs. 1-19; Krüger, Hildegard: "Función y estructura social del cabildo colonial de Asunción", Jahrbuch für Geschichte von Staat, Wirtschaft und Gesellschaft Lateinamerikas, núm. 18, Köln, 1981, págs. 31-44; Arteaga Zumorán y otros: Estudios sobre el cabildo de Santiago del Estero, siglo XVIII, Montevideo, 1982; Lohmann Villena, Guillermo: Los regidores perpetuos del cabildo de Lima (1535-1821), Sevilla, 1983; Gelman, Jorge Daniel: "Cabildo y élite local. El caso de Buenos Aires en el siglo XVII”, HISLA, núm. 6, Lima, 1985, págs. 3-20; Palma Murga, 
De todas formas, a la hora de intentar definir la actuación de las élites capitulares indianas como grupos de poder se podría afirmar que, al contrario de lo cabe apreciar en la organización institucional, el proceso fue de la unidad dentro de la diversidad, en la medida en que fueron muy similares los mecanismos de que se valieron para controlar las diferentes esferas de poder. Pero antes conviene analizar hasta qué punto el sistema de venta y renunciación de los oficios capitulares no electivos favoreció el acceso a los concejos municipales de grupos económicos y sociales que hasta entonces se habían visto de una forma u otra excluidos de los mismos. Basta con recordar que en el siglo XVI eran los beneméritos, es decir, los conquistadores y sus descendientes los que, avalados además por su condición de encomenderos, señoreaban en los cabildos de las diferentes ciudades.

En México, concretamente, el hecho de que la influencia y fuerza de los encomenderos se viera considerablemente mermada por la intensificación de la legislación real, no impidió que durante la mayor parte de la centuria fueran ellos los que controlaran, ya fuera por elección o por merced real, los cargos capitulares más relevantes. ${ }^{5}$ Otro tanto ocurrió en Perú, donde era manifiesta la situación de privilegio que gozaban los encomenderos en sus respectivos cabildos, al tener monopolizados los oficios de alcaldes ordinarios y ser, por tanto, los únicos árbitros de la justicia municipal con notorio perjuicio para los restantes vecinos. En este caso fue el virrey Toledo quien en 1570 trató de mermar los fueros y atribuciones de los poderosos encomenderos, ordenando que la elección de alcaldes ordinarios

Gustavo: "Núcleos de poder local y relaciones familiares en la ciudad de Guatemala a dinales del siglo XVIII", Mesoamérica, núm. 12, Guatemala/Vermont, diciembre 1986, págs. 241-308; Nicoletti, María Andrea: "El Cabildo de Buenos Aires: las bases para la confrontación de una mentalidad", Revista V Centenario, núm. 13, Madrid, 1987, págs. 97-127; González Rodríguez, Adolfo Luis: "El cabildo de Córdoba durante el siglo XVI: encomenderos, propietarios de tierras, tratantes de negros y comerciantes. Análisis de un grupo de poder”, Estudios de Historia Social y Económica de América, núms. 3-4, Alcalá de Henares, 1987-1988, págs. 29-45; Langue, Frédérique: “Antagonismo y solidaridades en un cabildo colonial: Caracas, 1750-1810”, Anuario de Estudios Americanos, vol. XLIX, Sevilla, 1992, págs. 371-393; Saguier, Eduardo: "La lucha contra el nepotismo en los orígenes de las Reformas Borbónicas. La endogamia en los Cabildos de Salta y Tucumán (1760-1790)”, Andes, Antropología e Historia, núm. 5, Salta, 1992, págs. 89-124; Martínez Ortega, Ana Isabel: Estructura y configuración socioeconómica de los cabildos de Yucatán en el siglo XVIII, Sevilla, 1993; González Muñoz, Victoria: Cabildos y grupos de poder en Yucatán (siglo XVII), Sevilla, 1994; Ponce Leiva, Pilar: Certezas ante la incertidumbre: Élite y cabildo de Quito en el siglo XVII, Quito, 1998; Pazos Pazos, María Luisa: El ayuntamiento de la ciudad de México en el siglo XVII: continuidad institucional y cambio social, Sevilla, 1999.

5 Gibson, Charles: Los aztecas bajo el dominio español (1519-1810), México, 1967, págs. 66-68; Israel, J. I: Razas, clases sociales y vida política en el México colonial, 1610-1670, México, 1980, pág. 101; Peña, José F. de la: Oligarquía y propiedad en Nueva España. México, 1983, págs. 147-148. 
y regidores se hiciera de forma que los nombramientos recayeran por igual entre encomenderos y vecinos no beneficiarios de encomiendas. ${ }^{6}$

Pero si esto sucedía en las regiones nucleares, con más motivo se daba en zonas periféricas, como Yucatán, Chile, Cartagena, Caracas, Quito, Popayán o Tucumán, donde por su misma marginalidad la encomienda acabó teniendo una mayor importancia y pervivencia. En Yucatán, por ejemplo, la hegemonía que los encomenderos llegaron a tener en los gobiernos de la capital y las villas fue casi total, no sirviendo de nada el mandato de la Audiencia de México en 1569 de que la elección se hiciese de forma que se turnasen en los oficios capitulares los encomenderos y vecinos "de tres en tres años", ni tampoco la propuesta del protector de los naturales en 1580 de que "la mitad de los alcaldes y regidores" fuesen "vecinos encomenderos y la otra mitad de pobladores que no tengan indios". Para los beneméritos este procedimiento electivo representaba una gran ofensa por considerar que eran ellos las únicas personas que debían "gozar de los dichos cargos y oficios y no los advenedizos, que no son de edad ni tienen hacienda para si algunos agravios hicieren poderlos pagar en residencia". El mismo predominio se dió en Chile, donde tampoco se acató la orden de la Audiencia de Concepción para que en el cabildo de Santiago la mitad de los oficios recayeran en los encomenderos y "la otra mitad en los demás vecinos y moradores de inferior situación económica". ${ }^{8} \mathrm{Y}$ análogo fenómeno se produjo en Cartagena, Caracas, Quito, Popayán y en Tucumán, al ser los encomenderos los que de forma clara prevalecían en el gobierno municipal. En Cartagena, por ejemplo, el dominio de los encomenderos era prácticamente absoluto, pues para 1565 el gobernador ponía de relieve cómo de los trece vecinos encomenderos de indios que había en la ciudad, ocho los había proveído el rey por regidores perpetuos y "éstos y yo elegimos cada año dos alcaldes, y siempre salen también encomenderos de indios". En Quito los encomenderos concibieron el cabildo durante el

6 Levillier, Roberto: D. Francisco de Toledo, supremo organizador del Perú. Su vida y su obra, Madrid, 1935, tomo I, págs. 233-239; Preston Moore: The Cabildo in Perú..., págs. 83-86; sobre la situación en el cabildo de Lima véase Lohmann Villena: Los regidores perpetuos..., págs. 196, 198 y 217.

7 García Bernal, Manuela Cristina: Población y encomienda en Yucatán bajo los Austrias, Sevilla, 1978, págs. 427-429. pág. 90).

8 Alemparte: El cabildo en Chile..., págs. 59, 84-85 y 89-91 (la cita textual corresponde a la

9 Ruiz Rivera, Julián B.: "Encomiendas y tributos en Cartagena de Indias entre los asaltos de Drake y de Pointis", Cuadernos de Historia Latinoamericana (AHILA), núm. 3, Münster, 1996, págs. 84-85 (la cita textual corresponde a la página 85); véase también Borrego Plá, $\mathbf{M}^{\mathrm{a}}$ Carmen: Cartagena de Indias en el siglo XVI, Sevilla, 1983, págs. 304 y 354-357. 
siglo XVI como un coto exclusivo, al tiempo que en Caracas un reducido grupo de encomenderos concentraba no sólo el poder económico y social, sino también el político a través de su presencia en el cabildo. ${ }^{10}$ En Tucumán, concretamente, fue la Audiencia de Charcas la que tuvo que mediar en el conflicto entre encomenderos o feudatarios y moradores o soldados, estableciendo su oidor Juan de Matienzo el reparto por igual de los cargos de alcaldes y regidores entre ambos grupos, pues sólo debían quedar excluidos "por vileza de oficio los mercaderes que tenían tienda pública de venta al menudeo, los oficiales de artes liberales y mecánicas y los que se alquilaban para trabajos agrícolas". Es decir, las actividades consideradas como indignas y, por tanto, incompatibles con la estimación requerida para desempeñar oficios públicos. Con todo, el oidor no dejaba de reconocer que la vileza de estas actividades dependía de la costumbre local y por ello la limitación impuesta no afectaba a los mercaderes en general, ni tampoco a las villas pequeñas, donde no había muchas otras posibilidades de ganarse la vida. ${ }^{11}$

Ante esta situación de práctico monopolio de los gobiernos municipales por parte de los encomenderos o beneméritos es evidente que la enajenación de algunos oficios concejiles ya desde el siglo XVI propició que en algunas regiones se iniciara el relevo de las élites capitulares, al no poder los benémeritos resistir el embate de los nuevos pobladores enriquecidos. ${ }^{12}$ En ello fue sin duda decisiva la mentalidad de unos hombres, como los encomenderos o sus descendientes, que vivían anclados en el pasado, intentando reconstruir una sociedad de signo medieval totalmente desfasa-

10 Ortiz de la Tabla Ducasse, Javier: "Modelos peninsulares en la estratificación social de Ecuador", en Europa e Iberoamérica: Cinco siglos de intercambios (Actas del IX Congreso Internacional de Historia de América, AHILA), Sevilla, 1992, vol. I, págs. 100-101 y 103, y Los encomenderos de Quito, 1534-1660, Sevilla, 1993, págs. 123-124; Langue, Frédérique: “Orígenes y desarrollo de una élite regional. Aristocracia y cacao en la provincia de Caracas, siglos XVI-XVIII", Tierra Firme, núm. 34, Caracas, abril-junio 1991, págs. 144-145.

11 Doucet: "Feudatarios y soldados...", págs. 384-390 (la cita textual corresponde a la pág. 386); véase también González Rodríguez: "El cabildo de Córdoba...”, págs. 34-36. Para Popayán consúltese González Rodríguez, Adolfo Luis: "La sociedad encomendera en la gobernación de Popayán durante el siglo XVII", en La encomienda en Popayán, Sevilla, 1977, pág. 354. Son asimismo válidas al respecto las consideraciones en torno a la mentalidad hidalga de los conquistadores y primeros colonizadores en Romero, José Luis: Latinoamérica: las ciudades y las ideas, $4^{\mathrm{a}}$ ed. Argentina, 1986, págs. 108-118.

12 La cédula de 1591 que ordenaba la venta con carácter vitalicio de todos los regimientos municipales que estuviesen vacantes supuso el tránsito de los regimientos "cadañeros" y electivos a los de carácter vitalicio de forma general, ya que hasta entonces la condición de vitalicios o perpetuos sólo la habían tenido los de merced real. Tomás y Valiente: La venta de oficios..., pág. 92; Haring, Clarence H.: El imperio hispánico en América, Buenos Aires, 1966, pág. 171. 
da, sobre la base de unas encomiendas cada vez menos rentables o de unas mercedes que creían les correspondían en justicia. No fueron capaces de comprender que en los albores del siglo XVII el linaje y los méritos habían perdido importancia frente a la riqueza que era la que ya operaba como verdadero agente de estratificación social. Su falta de realismo acabó mermando su capacidad económica y, por tanto, su influjo y poder.

Por todo ello no se puede negar que en cierto modo el sistema de ventas y renunciaciones de oficios que se consolidó en el siglo XVII suponía un retorno a los viejos principios igualitarios que habían marcado la constitución de los primeros núcleos urbanos en América y les había conferido un cierto carácter democrático. ${ }^{13}$ Ya no se podía alegar para ingresar en el cabildo la categoría social del aspirante, el linaje o la limpieza de sangre, ni tampoco se podía excluir a nadie del mismo por la vileza de sus actividades, ni por su condición de advenedizo y ni siquiera por su falta de pureza de sangre o de capacidad para desempeñar el cargo, puesto que lo único que interesaba a una monarquía en bancarrota eran los ingresos obtenidos por esta nueva vía. Se venía abajo así el tipo de sociedad señorial que los encomenderos y sus descencientes habían intentado fundar, ya que el dinero bastaba para disolver los tradicionales prejuicios respecto a la indignidad del origen o de ciertas actividades, como el comercio, la artesanía o la minería. La riqueza los igualaba a todos, desde el momento en que los oficios eran concebidos como mercancías susceptibles de compra y venta. Ahora bien, es evidente que esta aparente "democratización" era relativa, pues al primar el factor económico se hacía inevitable la composición oligárquica de los ayuntamientos, dado que éstos pasarían a estar dominados por los grupos sociales que en cada ciudad o región tuviesen el poder económico.

Por supuesto, el proceso no fue igual en todos los territorios indianos. Lógicamente, cada región, cada ciudad, marcó su impronta e impuso su ritmo. Pero lo cierto es que a principios del siglo XVII el cabildo de México, destacado centro de poder por la riqueza e importancia de la ciudad, ya se había convertido, en "una especie de universidad de mercaderes", al estar integrado en casi un $75 \%$ por mercaderes e hijos de éstos y apreciarse una notoria ausencia de los linajes tradicionales que sólo lograban mantener su presencia y poder a través de las alcaldías ordinarias. Como contraste, el

13 Parry: The sale of public office..., pág. 70; Haring: El imperio hispánico..., pág. 170; Carrera Stampa, Manuel: "Las actas municipales, fuente de la historia de México", en Altamira y Crevea, Rafael y otros: Contribuciones a la historia municipal de América, México, 1951, pág. 111. 
concejo de Puebla mantenía en 1620 un corte más tradicional, ya que la pérdida de posiciones acusada por el grupo benemérito no significó su desaparición del poder municipal. Es más, la presencia de grupos nuevos de origen mercantil u obrajero no impidió la cohesión del cabildo poblano que se mostraba fuertemente trabado por lazos económicos y de parentesco. ${ }^{14}$ Por su parte, el cabildo de Santiago de los Caballeros de Guatemala también presenció el eclipse de los conquistadores y sus descendientes encomenderos, virtuales señores del mismo durante la mayor parte del siglo XVI. ${ }^{15}$ La venta de oficios posibilitaría el ingreso en la corporación municipal de importantes y activos mercaderes y con ello la ruptura del predominio de los beneméritos. Está claro que los criollos tuvieron que ceder ante el poder económico de los "recién llegados" y, aunque lograron, como los de Puebla, asegurar su permanencia en el concejo, éste perdió su carácter de "cerrado" para pasar a constituir un organismo abierto a elementos exógenos y, por tanto, mucho más permeable. ${ }^{16}$

Un proceso similar al de la capital mexicana se puede apreciar en Lima, la otra sede virreinal, y también en Potosí, Cartagena y Buenos Aires. En el cabildo limeño el repliege de los encomenderos era ya incuestionable para la última década del siglo XVI ante la progresiva pérdida de rentabilidad de las encomiendas y el empuje de los mercaderes, rentistas y hacendados. Sin embargo, serían éstos últimos los que conforme avanzaba el siglo XVII irían copando los oficios capitulares, asentando una hegemonía que se mantendría inalterable hasta los albores del siglo XIX. ${ }^{17} \mathrm{Y}$ otro tanto sucedió en Potosí, donde el gremio de los azogueros, el grupo de mayor poder adquisitivo, consiguió desplazar de las plazas edilicias a los descendientes de los conquistadores. ${ }^{18}$ De igual forma, en Cartagena la enajenación de los oficios provocó una redistribución de fuerzas en el seno del gobierno municipal, hasta el punto de que la primitiva aristocracia encomendera, después

14 Peña: Oligarquía y propiedad..., págs. 149-152 y 166; esta presencia creciente de comerciantes es confirmada por Pazos Pazos: El ayuntamiento de la ciudad de México..., págs. 335-339; Hoberman, sin embargo, considera que el relevo que asumieron los mercaderes en el concejo de la capital mexicana fue más atenuado, pues para 1610 sólo representaban el 25\%. Hoberman, Louisa S.: Mexico's Merchant elite, 1590-1660. Silver: State, and Society, Durham and London, 1991, pág. 158.

15 Chinchilla Aguilar, Ernesto: El ayuntamiento colonial de la ciudad de Guatemala, Guatemala, 1961, pág. 173; Sanchiz Ochoa, Pilar: Los hidalgos de Guatemala. Realidad y apariencia en un sistema de valores, Sevilla, 1976, págs. 98 y 131.

16 Peña y López Díaz: “Comercio y poder...”, págs. 496-497 y 502; Webre: "El cabildo de Santiago de Guatemala...”, págs. 16 y 18-19.

17 Lohmann Villena: Los regidores perpetuos..., págs. 218-221.

18 La referencia al cabildo de Potosí aparece en Krüger: "Función y estructura social...”, pág. 38. 
de haber tenido un dominio casi absoluto del cabildo a lo largo del siglo XVI, sólo logró mantener una representación minoritaria. Su lugar lo ocuparon individuos que habían medrado en otros sectores productivos, como el comercio de esclavos, y cuyo origen extranjero - portugués en su mayoría- era en no pocos casos soslayado por su poder económico. ${ }^{19} \mathrm{Y}$ lo mismo se podría decir de la situación en el Río de la Plata y, más en concreto, en el cabildo de Buenos Aires, donde la compra de oficios facilitó el acceso al gobierno municipal de un buen número de comerciantes, en su mayoría también portugueses, que compensaban el exiguo o nulo aprovechamiento económico que "oficialmente" proporcionaban los cargos edilicios con los pingües beneficios indirectos que podían rendir merced a la connivencia con las redes de tráfico ilícito, algo que parece llegó a ser un fenómeno estructural en el desarrollo de la capital rioplatense. ${ }^{20}$

En cambio, hubo zonas de la periferia en las que por sus peculiares características tal desplazamiento no se produjo. Un buen ejemplo al respecto lo constituyó Zacatecas, cuyo ayuntamiento no perdió nunca su carácter representativo de la ciudad y de sus intereses, al nutrirse "casi por definición" de mineros y de aquellos comerciantes que tenían estrecha vinculación con la producción argentífera. No en balde Zacatecas dependía de su riqueza de plata y, como apunta Bakewell, "lo que convenía a la plutocracia minera y mercantil quizá también convenía, en términos generales, al pueblo en su conjunto". ${ }^{21}$ También el cabildo de Panamá puede ser representativo en este sentido, por cuanto allí fueron los comerciantes los que mantuvieron la primacía que ya se habían asegurado en el siglo XVI, dado su carácter de enclave y lugar de tránsito mercantil..$^{22}$ Aunque quizá el mejor exponente de su particular idiosincrasia lo brindó Yucatán, pues la pobreza y marginalidad de la región determinaron que la encomienda desempeñara el papel de institución clave en su proceso colonizador y lle-

19 Ruiz Rivera, Julián B.: "Cartagena de Indias: municipio, puerto y provincia (1600-1650)", en Actas del XI Congreso Internacional de AHILA, Liverpool, 1998, vol. II, pág. 362, y "Encomiendas y tributos en Cartagena...", pág. 84-85.

20 Zorraquín Becú: “Los cabildos...”, págs. 24-26 y 51-52; Gelman, Jorge Daniel: "Economía natural-economía monetaria (Los grupos dirigentes de Buenos Aires a principios del siglo XVII)", Anuario de Estudios Americanos, vol. XLIV, Sevilla, 1987, págs. 99-100; Moutoukias, Zacarías: Contrabando y control colonial en el siglo XVII, Buenos Aires, 1988, págs. 63 y 114-115; Socolow, Susan: Los mercaderes del Buenos Aires virreinal: familia y comercio, Buenos Aires, 1991, pág. 23.

21 Bakewell, Peter J.: Minería y sociedad en el México colonial. Zacatecas (1546-1700), México, 1976, pág. 143.

22 Mena García, M ${ }^{\mathrm{a}}$ del Carmen: La sociedad de Panamá en el siglo XVI, Sevilla, 1984, págs. 243-245. 
gara a tener una vigencia excepcionalmente dilatada. Los encomenderos, pese a su indiscutible mentalidad señorial, no dudaron en buscar nuevas fuentes de ingreso cuando el deterioro económico de las encomiendas se hizo evidente. De esa forma en los cabildos de Mérida y Valladolid la venta de los oficios concejiles no significó su relevo, ni su debilitamiento como grupo de presión, al ser ellos los que controlaban los escasos recursos económicos. Es más, para los no beneméritos el acceso a estos cabildos se convirtió, a su vez, en una vía de ingreso en el reducido elenco de los beneficiarios de encomiendas, porque su intención no fue nunca la de hacer la competencia a la poderosa élite encomendera, sino de integrarse en ella. Con ello se fortaleció aún más el poder casi omnímodo que los encomenderos tenían en su gobierno y administración. Sin embargo, en el ayuntamiento de Campeche sí que se pudo apreciar un cambio significativo en cuanto a su composición socio-económica, pues serían los comerciantes los que, por su mayor vinculación con los intereses marítimos y mercantiles de la villa, aprovecharían el mecanismo de la venta de oficios para dominar el gobierno municipal. Ahora bien, aunque este caso constituye una muestra más del amplio abanico de respuestas que la enajenación de oficios tuvo en las Indias, conviene precisar, sin embargo, que en Campeche al empuje de los comerciantes se unió también un cierto abandono por parte de los encomenderos, para quienes era más apetecible residir en Mérida y Valladolid, donde su condición social sería mucho más reconocida. De todos modos, serían las oligarquías locales, viejas y nuevas, las que a la postre controlarían las corporaciones municipales yucatecas. ${ }^{23}$

Un proceso semejante se dio también en los cabildos de Caracas y Asunción, donde la venta de oficios no logró alterar su conformación social. Mientras que en la capital venezolana los encomenderos supieron sacar partido del desarrollo del cultivo cacaotero para mantener su posición en el concejo, en Asunción fue la precaria estructura económica de la zona - basada en una agricultura exigua, en unas encomiendas de muy pocos tributarios y en la explotación yerbatera- la que no propició el desplazamiento social. El cabildo siguió controlado por una élite capitular y militar tradicional que acaparaba las pocas fuentes de riqueza y que, por tanto, era la única con capacidad económica para adquirir los cargos edi-

23 García Bernal: Población y encomienda..., págs. 366-373, 431 y 437-438; García Bernal, Manuela Cristina: "La aristocracia de Yucatán (siglo XVII), en América: encuentro y asimilación (Actas de las Segundas Jornadas de Historiadores Americanistas), Granada, 1989, págs. 323-327; González Muñoz: Cabildos y grupos de poder..., págs. 126-127 y 132-142. 
licios..$^{24}$ Mucho más peculiar, sin embargo, fue el caso de Chile, donde la enajenación de los oficios capitulares provocó en 1612 la reacción de los encomenderos o feudatarios frente a las pretensiones de un grupo de "hombres nuevos". El cabildo de Santiago de Chile, con el fin de salvaguardar la libre elección de sus regidores, propuso pagar la misma cantidad a que habían ascendido las posturas de los oficios subastados. Fue así como, según Góngora, el cabildo logró afirmar "el principio electivo contra el fiscalismo monárquico, a la vez que la selección aristocrática contra el ascenso incontrolado de hombres nuevos". ${ }^{25}$

Es, por tanto, evidente, que la aparente carga igualitaria o democratizadora que podía conllevar el sistema consolidado en 1606 es discutible, toda vez que lo único que este sistema propició fue la constitución de un patriciado urbano privilegiado que concebía el cabildo como una estructura de poder que podía utilizar en beneficio propio. La venta de oficios fue, pues, el mecanismo idóneo que la Corona puso para ello en manos de los grupos más poderosos económicamente. Por ello, a la larga, el posible relevo de las élites capitulares no pasó de una simple alternancia de las oligarquías locales en el gobierno municipal. ${ }^{26}$

Al mismo tiempo, como ya se apuntó al principio, el sistema de renunciaciones impuesto en 1606 coadyuvaba a que la administración municipal pudiera acabar monopolizada por un pequeño círculo de familias ricas e influyentes, vinculadas en no pocos casos por lazos de parentesco y cuyos intereses no siempre coincidían con los de la comunidad que representaban. Qué duda cabe que la renuncia de los oficios a favor de parientes más o menos directos fue un factor decisivo para el control de determinados cargos por una sola familia. Es más, al combinarse las renuncias con las compras de los cargos vendibles y el posible acceso a los oficios electivos, se favoreció también la presencia simultánea de miembros de una misma familia en el ayuntamiento. Todo contribuía a que, en último término, se acabaran consolidando verdaderas dinastías capitulares.

24 Langue: "Orígenes y desarrollo...”, pág. 147; Krüger: "Función y estructura social...", págs. 37-39.

25 Góngora, Mario: Encomenderos y estancieros. Estudios acerca de la constitución social aristocrática de Chile después de la conquista, 1580-1660, Santiago de Chile, 1970, págs. $77-79$ y 126; Una situación similar se dio en el cabildo de Caracas en 1650 con motivo de la venta del oficio de alguacil mayor, al ofrecer el cabildo el doble de lo establecido en el remate público e impedir que el comprador pudiese tomar posesión del cargo. Arcaya: El cabildo..., págs. 71-72.

26 Sobre el carácter democrático del cabildo véase también Molina Martínez, Miguel: El municipio en América. Aproximación a su Desarrollo Histórico, Granada, 1996, págs. 94-96. 
Como siempre, las situaciones fueron muy diversas en función de las características de cada municipio. No hay que olvidar que en muchos ayuntamientos pudieron influir una serie de factores para obstaculizar la formación de dinastías familiares. Un factor a tener en cuenta fue lo oneroso que resultaba el desempeño de los cargos, al ofrecer "poco aprovechamiento" y constituir más bien una carga económica para los que lo ejercían, pues en no pocos casos tenían que suplir de sus haciendas los gastos que la administración municipal demandaba. También pudo influir la posibilidad de conseguir unos buenos ingresos mediante la venta del cargo bajo la forma de una renuncia, desde el momento en que los oficios se convirtieron en un bien como cualquier otro, susceptible de compra y venta. ${ }^{27}$

Pero los estudios realizados parecen demostrar que las élites capitulares indianas aplicaron unas estrategias comunes a la hora de expandir su poder, influencia y riqueza. Volvemos así a la idea de que en este sentido el proceso fue de la unidad dentro de la diversidad. Uno de los mecanismos para consolidar su posición y adquirir cohesión y poder lo constituyeron las alianzas matrimoniales y las prácticas endogámicas que dichas élites llevaron a cabo en la mayor parte de los territorios indianos. Es más, en algunas zonas como, por ejemplo, Yucatán o Paraguay, el dominio de los cabildos por determinados clanes familiares se debió más a la férrea endogamia aplicada por las oligarquías locales en su política matrimonial que a la venta y renuncia de los oficios que, en estos casos, lo único que hizo fue acentuar el proceso ${ }^{28}$ En cambio, hubo municipios en los que, quizá por el corte menos aristocrático de sus élites capitulares, las alianzas matrimoniales no adoptaron un carácter tan endógámico y ello, lógicamente, posibilitó la constante circulación de individuos y familias dentro del gobierno municipal, restringiéndose así las posibilidades para la formación de dinastías capitulares. Campeche, Guatemala o Zacatecas pueden ser bien representativos a este respecto, pues sus ayuntamientos, al estar dominados por comerciantes y mineros, no lograron adquirir la misma cohesión y estabilidad social. ${ }^{29}$

27 Zorraquín Becú: “Los cabildos...”, págs. 24-25; García Bernal: Población y encomienda..., págs. 435-437; Lohmann Villena: Los regidores perpetuos..., pág. 215; González Muñoz: Cabildos y grupos de poder..., págs. 69, 98-99, 124 y 130.

28 García Bernal: Población y encomienda..., págs. 468-470; González Muñoz: Cabildos y grupos de poder..., págs, 123-124, 130-131 y 248; Krüger: "Función y estructura social...", páginas 39-43. Sobre la aplicación de la endogamia en otros espacios y tiempos véase Nicoletti: "El Cabildo de Buenos Aires...", pág. 112; Saguier: "La lucha contra el nepotismo...”, págs. 89-124.

29 González Muñoz: Cabildos y grupos de poder..., págs. 141, 274-275; Webre: "El cabildo de Santiago de Guatemala...”, págs. 8-18; Bakewell: Minería y sociedad..., pág. 142. 
De todas formas, parece indudable que el matrimonio jugó en las Indias un papel decisivo en la constitución de una bien trabada urdimbre de intereses económicos y familiares que permitió a los grupos poderosos regir el escenario político, económico y social. ${ }^{30}$ Lógicamente, el cabildo constituía un espacio de poder que se quería mantener y expandir. Y para ello fue sin duda decisiva la formación de complejas redes de parentesco, dado que, como apunta Foucault, el poder no es estático, "no está quieto en los individuos", porque es algo que circula, "que no funciona sino en cadena", y que "se ejercita a través de una organización reticular". ${ }^{31}$ En otras palabras, en el cabildo existía, como en cualquier otro espacio de poder, una tensión, una lucha permanente por conservar para sí ese flujo de poder, al ser un bien como cualquier otro y resultar por ello difícil el poseerlo indefinidamente. Muchos ayuntamientos constituyeron así el ámbito en el que las familias de las que se nutría la élite capitular se unían o se enfrentaban en función de problemas comunes o de intereses familiares.

Con mayor o menor fortuna las oligarquías indianas lograron reproducirse y estar presentes en las corporaciones municipales a través de estrechos lazos de parentesco con el fin de acaparar el poder, el prestigio y la riqueza. Ese fue uno de sus mecanismos en las dos capitales virreinales donde se concentraban todas las esferas del poder. En México, las familias poseedoras de grandes fortunas y patrimonios lograron dilatar el mundo de sus relaciones e influencias políticas, gracias a la sabia política matrimonial que practicaron. Aquí sí que se combinaron endogamia y venta de oficios para que estas familias poderosas fueran poco a poco controlando los cabildos, penetrando en las audiencias y acaparando las alcaldías mayores y los corregimientos. Y si se tiene en cuenta que la institución del mayorazgo fue el otro mecanismo legal del que este grupo, de marcado carácter aristócrático, se sirvió para conseguir la continuidad del linaje y de las riquezas adquiridas, se comprende fácilmente que este reducido círculo de hombres poderosos fuera, según De la Peña, el verdadero núcleo catalizador de la nobleza mexicana. ${ }^{32}$ Un proceso similar se reprodujo en la capital

30 Sobre las "prácticas efectivas" de las élites indianas y los planteamientos metodológicos al respecto véase Langue, Frédérique: “¿Estrategas o patriarcas? La aristocracia empresarial zacatecana a fines del siglo XVIII-principios del siglo XIX”, en Schröter, Bernd y Christian Büschges (eds.) Beneméritos, aristócratas y empresarios. Identidades y estructuras sociales de las capas altas urbanas en Iberoamérica colonial, Frankfurt/Main-Madrid, 1999, págs. 275-278.

31 Foucault, Michel: Microfísica del poder, Madrid, 1992, pág. 144.

32 Peña: Oligarquía y propiedad..., págs. 168-171, 181-190 y 236-237; véase también Pazos Pazos: El ayuntamiento de la ciudad de México..., págs. 328-335. 
peruana en cuyo cabildo llegaron a establecerse ciertas dinastías familiares en las que el cargo capitular, al resultar prácticamente hereditario, se consideraba como algo patrimonial. Lohmann Villena pone de relieve que, aunque sea exagerado definir al cabildo como "una familia de familias", no se puede negar la enorme gravitación que en el ayuntamiento limeño tuvieron las marañas de parentesco que se formaron, así como su importancia para "elevar el índice de cohesión entre los capitulares y afianzar sus relaciones de afecto recíproco". ${ }^{33}$

Lo cierto es que la formación de camarillas y parentelas dentro de los cabildos se dio en la mayoría de los municipios indianos. Fueron manifiestas en Santiago de Chile y en La Serena, hasta el punto de que el corregidor de este último municipio denunciaba en 1636 cómo las dos principales familias estaban emparentadas por afinidad o consaguinidad con toda la ciudad, de modo que "la causa de uno, por leve que sea, la reputan todos por propia y salen a ella, como está dicho, con alboroto y escándalo de toda la ciudad" ${ }^{34}$ Tal fenómeno no fue tampoco extraño en el cabildo bonaerense donde el grupo de comerciantes se consolidó relativamente pronto económica y socialmente, gracias a sus conexiones con el comercio lícito e ilícito, convirtiéndose por ello en el principal rival del grupo benemérito por la supremacia en la administración municipal. Sin embargo, al igual que ocurrió en los cabildos de Mérida y Valladolid de Yucatán, su progresiva hegemonía no significó necesariamente la sustitución de la inicial aristocracia encomendera o benemérita por los "nuevos ricos", sino lo que algunos autores definen como "autotransformación de la élite", al darse una fructífera relación parental y económica entre los terratenientes o beneméritos y los comerciantes contrabandistas. Se constituyó así en el cabildo rioplatense una amplia red de notables que integraban tierra, comercio y administración. ${ }^{35} \mathrm{Y}$ tampoco se puede olvidar a este respecto los casos de Quito y La Paz, dado que también allí se formó una compleja red de enlaces familiares y afinidades entre las élites, como medio de promoción y preservación del poder, la riqueza y el prestigio social. De ahí que pueda ser tam-

33 Lohmann Villena: Los regidores perpetuos..., págs. 205-211 (la cita textual corresponde a la página 205).

34 Góngora: Encomenderos y estancieros..., pág. 75.

35 Moutoukias, Zacarías: "Burocracia, contrabando y autotransformación de las élites", Anuario del Instituto de Estudios de Historia Social (IEHS), núm. 3, Tandil, 1988; Gelman: "Cabildo y élite local...", págs. 3-20, y "Economía natural-economía monetaria...”, págs. 98-99. Sobre las redes de parentesco en el Buenos Aires del siglo XVIII véase Socolow: Los mercaderes..., págs. 49-65. 
bién considerado como un buen exponente de lo que se ha dado en llamar la "circulación de las élites". ${ }^{36}$

Ahora bien, ¿a qué se debía el interés de las poderosas familias por instalarse en los cabildos? ¿Qué era lo que les aportaba el control del gobierno local? Indudablemente prestigio social, algo nada desdeñable en una sociedad donde la tendencia al ennoblecimiento se mantuvo inalterable, incluso entre los nuevos grupos emergentes, a lo largo de todo el período colonial. Y es que por principio los cargos capitulares no propiciaban fáciles y rápidos beneficios, si se tiene en cuenta que su ejercicio no implicaba la obtención automática de un ingreso económico, toda vez que nunca tuvieron un salario fijo a cargo del erario real, sino de sus respectivas corporaciones, lo que en la práctica suponía su inexistencia ante la falta o escasez de propios que padecían muchas ciudades indianas. Es más, en la mayoría de los casos dichos oficios exigían desembolsos personales, ya fuera para costear los festejos, ya para satisfacer los gastos normales que demandaba la ciudad o, en los casos extremos, para hacer frente a situaciones críticas en épocas de catástrofe. Cierto que algunos puestos edilicios, como las escribanías, depositarías, alguacilazgos y fieles ejecutorías, ofrecían ciertos beneficios económicos, al incluir el cobro de determinados derechos por el desempeño de sus funciones, como, por ejemplo, el 2,5\% que cobraba el depositario general por los depósitos que recibía, o los porcentajes que percibía el alguacil mayor por las ejecuciones o denuncias que efectuaba. ${ }^{37}$ Pero, lógicamente, la importancia de estos beneficios estaba en función del tamaño del municipio y de su actividad económica.

Por tanto, si lo que se buscaba era un posible enriquecimiento, es evidente que éste sólo se podría alcanzar por medios ilícitos, es decir, sabiendo utilizar el prestigio y las prerrogativas de los cargos en beneficio propio. Y no cabe duda de que éste fue otro de los mecanismos de que las élites capitulares y, en última instancia, las oligarquías locales se valieron para afianzar su poder económico. Por supuesto, resulta obvio que las oportuni-

36 Ponce Leiva: Certezas ante la incertidumbre..., págs. 280 y 285-296; López Beltrán, Clara: "El círculo del poder. Matrimonio y parentesco en la élite colonial: La Paz", Revista Complutense de Historia de América, núm. 22, Madrid, 1996, págs. 161-181. Sobre el proceso en general véase Balmori, Diana, Stuart F. Voss y Miles Wortman: Las alianzas de familias y la formación del país en América Latina, México, 1990, págs. 253-294.

37 Sobre las competencias y prerrogativas de los oficios capitulares véanse Avellá Vives: Los cabildos..., y Bayle: Los cabildos seculares...; González Muñoz hace una síntesis muy exhaustiva sobre las funciones de los diferentes cargos, así como sobre sus ventajas e inconvenientes, estableciendo además las peculiaridades que adoptaron en los cabildos yucatecos. González Muñoz: Cabildos y grupos de poder..., págs.26-89. 
dades de lucro serían mayores si la capacidad de intervención y decisión se extendía a varias esferas de la administración municipal, pues con ello se reforzaría su influencia y poder. A este respecto cabe señalar la significación que tenían cargos como los de alguacil, fiel ejecutor o depositario general, en cuanto que, al combinarse con los regimientos en algunos ayuntamientos (por ejemplo, los yucatecos), conjugaban las funciones de su exclusiva competencia con las que les correspondían como regidores. Es decir, tenían asegurada su presencia en todos los ámbitos de la administración municipal. Y en este sentido, puede decirse que también los regidores, al asumir dichas funciones, ampliaban su campo de actuación, ya de por sí bastante extenso, toda vez que ningún asunto de sus respectivos municipios escapaba a su intervención y control. ${ }^{38}$

Lógicamente, fueron las atribuciones en materia económica, como el control de los productos, el abastecimiento de las poblaciones o la fijación de precios y aranceles, las que aprovecharon las élites capitulares para lucrarse, buscando más su propio beneficio que el de las comunidades que representaban. Así se puso de relieve, por ejemplo, en Yucatán, donde se acusó al cabildo de Mérida del encarecimiento de la carne, precisamente en una época en que las estancias de ganado se multiplicaban. La denuncia se basó en el hecho de que el aumento de los precios se debía en realidad al monopolio que ejercían los grandes estancieros en el abasto de la carne y a sus manejos pues, al ser hombres poderosos por sus oficios en el cabildo distribuían las semanas para el abasto de Mérida a su capricho, reservándose las épocas mejores y, consecuentemente, imponiendo ellos los precios. ${ }^{39}$ Y otro tanto ocurrió con el abastecimiento de maíz, canalizado a través del pósito y la alhóndiga, en tanto que se dieron casos en que los regidores, al tener responsabilidades directas sobre este ramo, aprovecharon sus atribuciones para sacar beneficio económico, vendiendo el maíz por su cuenta en épocas de carestía. ${ }^{40}$ Pero también en Lima los regidores supieron sacar partido de su privilegiada situación para enriquecerse dolosamente, tanto más cuanto para la década de 1620 los regidores y sus deudos eran "dueños y señores de casi todas las chácaras y heredades del contorno de la ciudad".

38 González Muñoz: Cabildos y grupos de poder..., págs. 114-115.

39 García Bernal, Manuela Cristina: "La explotación pecuaria y la competencia por la tierra en torno a Mérida de Yucatán”, Temas Americanistas, núm. 8, Sevilla, 1990, pág. 32.

40 González Muñoz: Cabildos y grupos de poder..., pág. 68; González Muñoz, Victoria: "El cabildo de Mérida y la alhóndiga: sus implicaciones institucionales", y García Bernal, Manuela Cristina: "El cabildo de Mérida y el abastecimiento de la alhóndiga en el siglo XVII", en Actas del XI Congreso Internacional de AHILA, Liverpool, 1998, vol. II, págs. 385 y 399-400, respectivamente. 
Así, en connivencia con los alcaldes y fieles ejecutores imponían unos precios a los productos de primera necesidad, como el trigo o la carne, que sólo favorecían sus conveniencias particulares. El mismo virrey llegó a denunciar tal prevaricación, exponiendo al rey cómo las haciendas de los veintidós regidores limeños consistían "en granjerías del campo, huertas, chácaras, viñas y otras inteligencias, de manera que los bastimentos de pan, vino, aceite y frutas que se gastan en ella [la ciudad de Lima] son de sus cosechas y de sus deudos, con que hacen las posturas a los precios que quieren, de que se sigue perjuicio a los vecinos" ${ }^{41}$ Y lo mismo ocurrió en Chile, pues en el concejo de La Serena eran los capitulares-encomenderos los que dominaban la producción vitícola y los que, en consecuencia, marcaban los altos precios del vino. ${ }^{42}$

Pero tampoco cabría olvidar los efectos que en algunas ciudades tuvieron las competencias que en materia hacendística se delegó en la primera época en los ayuntamientos. Y es que hasta bien entrado el siglo XVII los oficiales reales eran considerados miembros ex officio de los cabildos, ya que contaban con voz y voto en los mismos y participaban por ello en la administración municipal con los mismos derechos que los regidores. En principio su función era la de salvaguardar los intereses reales dentro de las corporaciones locales, pero a la larga, el establecimiento de lazos familiares o de conexiones económicas acabaría por crear una comunidad de intereses con los demás miembros del cabildo y, por tanto, una influencia en asuntos hacendísticos no siempre favorable para el erario real. Sin embargo, el hecho de que en la década de 1620 se decretara su exclusión de los gobiernos municipales y perdieran su calidad de miembros ex officio truncó las posibilidades de enriquecimiento ilícito que tal combinación podía generar. Así ocurrió en Zacatecas y en Quito donde hasta 1620 y1621, respectivamente, los oficiales reales ocupaban dos o tres de los regimientos de forma permanente..$^{43}$ Pero hubo zonas, como Yucatán, donde dicha exclusión fue relativa, al hacerse efectiva sólo en Mérida, la capital, pero no en las villas de Valladolid y Campeche, donde los oficiales reales no asistían comúnmente. Allí se mantuvo la práctica, autorizada por la Corona en 1580, de que todo el cabildo o varios capitulares — un alcalde, un regidor y el escribano- se encargaran de cobrar los derechos reales para luego

\footnotetext{
41 Lohmann: Los regidores perpetuos..., págs. 221-222.

42 Góngora: Encomenderos y estancieros..., pág. 75.

43 Bakewell: Minería y sociedad..., págs. 137 y 140; Ponce Leiva: Certezas ante la incertidumbre..., págs. 158-159.
} 
remitirlos a los oficiales reales de Mérida. Y así fue como en Campeche los capitulares ejercieron la administración hacendística hasta 1665, mientras que en Valladolid conservaron su control a lo largo de todo el siglo XVII. Como consecuencia de ello, se denunciaron por parte de los funcionarios reales situaciones de fraudes y excesos que perjudicaron sensiblemente a la economía de la provincia y, sobre todo, a la propia Corona. Al principio las denuncias afectaban a los tres cabildos, al detectarse en 1616 notables encubrimientos en el cobro de las alcabalas por efectuarlo personas ocupadas "en oficio de república y con encomiendas y son hijos, yernos y deudos de encomenderos", todos ellos interesados en las alcabalas. En realidad, el hecho de que los alcaldes, regidores y escribanos de los tres cabildos fueran también "los tratantes y mercaderes de más consideración y muy emparentados" propiciaba un fraude general, al no pagar ellos los derechos reales que les correspondían, ni dar cuenta de todo lo que cobraban. Posteriormente sería, sobre todo, el ayuntamiento de Campeche el que más irregularidades presentaría, al ser sus alcaldes y regidores "las personas más ricas y emparentadas de dicho puerto y que de ordinario todos tienen navíos y fragatas... y ocultan y usurpan los derechos reales y vienen a ser jueces y visitadores de sus propias causas y navíos". El resultado fue que disminuyó sensiblemente la recaudación de alcabalas y almojarifazgos, a pesar de que las contrataciones y navegaciones por tierra y mar habían ido progresivamente aumentando. Y otro tanto ocurrió con la administración hacendística en Valladolid, aunque allí por su mayor pobreza las repercusiones fueran menores, beneficiándose los capitulares en la medida en que podían evadir algunos de los impuestos a que como encomenderos estaban obligados o aprovechar su función recaudadora para exigir repartimientos de géneros a los indios. ${ }^{44}$ Son, pues, muchos los ejemplos sobre las consecuencias que tenía el que los cabildos indianos se hubieran convertido en una instancia oligárquica, desde la cual se adoptaban decisiones que afectaban a una colectividad, pero que sólo generaban sustanciosos dividendos para un reducido sector de la misma.

Por otra parte, tampoco se puede olvidar cómo el control del gobierno municipal sirvió a las oligarquías locales como mecanismo para asumir el poder político a nivel gubernamental y aumentar así sus cotas de influencia o para defender sus intereses frente a las otras autoridades civiles o religiosas.

44 García Bernal: Población y encomienda..., págs. 438-441; González Muñoz: Cabildos y grupos de poder..., págs. 171-179. 
$\mathrm{Y}$ aunque, por lo general, se dio un cierto equilibrio de poder entre todas ellas, parece demostrado que en el trasfondo de muchos de los conflictos que se generaron entre algunos concejos y los representantes de los otros poderes, como el judicial, gubernamental o el eclesiástico, estuvo su ambición de extraer el máximo provecho de los recursos de sus respectivas regiones.

A este respecto es indudable que para los cabildos fue muy importante la facultad que tenían los alcaldes ordinarios de acceder al gobierno de la provincia en caso de ausencia o muerte de la primera autoridad, por cuanto constituía una fuente de poder y prestigio y también una oportunidad para aprovechar la situación en beneficio propio y de sus amigos y parientes. De ahí que los alcaldes ordinarios no dudaran en hacerse con el gobierno siempre que la ocasión se presentaba, pasando incluso por alto los derechos que a este respecto tenían los tenientes de gobernador, con los que sí entraron en conflicto al ser los verdaderamente afectados por el uso y abuso de tal prerrogativa. Y no en pocos casos ello derivó en un notorio perjuicio para sus respectivos distritos, como sucedió en Yucatán, donde entre 1619 y 1620 , al asumir los alcaldes el gobierno provincial por muerte del primer mandatario, se produjo una grave confusión jurisdiccional y política y un notable debilitamiento de sus posibilidades de defensa, al quedar la provincia "hecha una sierpe de siete cabezas, sin reconocerse la una a la otra, dos en esta ciudad [Mérida], dos en la villa de San Francisco de Campeche, dos en la de Valladolid y una en la de Salamanca de Bacalar". ${ }^{45}$

Sin embargo, los motivos de conflicto más frecuentes entre los concejos y las autoridades gubernativas, y donde más se revelaría la función de contrapeso del poder local frente al provincial, provinieron de la intromisión de la Audiencia (por las competencias gubernativas otorgadas en algunos casos a su presidente) o de los gobernadores en las elecciones capitulares y de la resistencia de los cabildos a aplicar determinadas disposiciones que de alguna forma lesionaban los intereses de los grupos dominantes. Está claro que las presiones ejercidas por la Audiencia o los gobernadores en las elecciones municipales con el propósito de instalar en el gobierno municipal a personas de su conveniencia provocó verdaderos altercados en no pocos cabildos, al verse directamente afectadas las familias más representativas de los diferentes municipios. Altercados que en bastantes ocasiones se solucionaron, como en Quito o Yucatán, mediante enlaces entre capi-

45 González Muñoz: Cabildos y grupos de poder..., págs. 149-154 (la cita textual corresponde a la página 149). 
tulares y familiares de magistrados o involucrándose algunos de los miembros del concejo en los negocios de los gobernadores. De esta forma las élites capitulares aprovechaban la connivencia con los primeros mandatarios como sistema de defensa de sus prerrogativas y empresas económicas. Pero no ocurrió lo mismo cuando las autoridades gubernativas trataron de aplicar determinadas contribuciones que chocaban de lleno con los intereses de las oligarquías que ellos representaban. Fue entonces cuando la reacción de los concejos frente a las instancias gubernativas se mostró quizá con más virulencia. ${ }^{46}$ Hubo casos, sin embargo, en que los conflictos partieron de los propios cabildos, al intentar asumir competencias económicas que en gran medida sólo beneficiaban a algunos de sus miembros más poderosos. Así se manifestó en Guayaquil, cuando desde mediados del siglo XVII su ayuntamiento trató de controlar la explotación forestal frente a la resistencia del gobierno colonial. ${ }^{47}$

Por último, también en las relaciones con las instancias eclesiásticas hay ciertos indicios de cómo los cabildos actuaron en muchas ocasiones condicionados por su carácter oligárquico. A nivel general son pocos los testimonios que existen sobre los posibles enfrentamientos entre las corporaciones municipales y la Iglesia, quizá porque no se dieron con demasiada frecuencia o no revistieron suficiente importancia, o quizá también porque, como en el caso de México, los lazos de parentesco entre capitulares y la jerarquía eclesiástica contribuían a suavizar las tensiones. En realidad, los ayuntamientos sólo entraron en verdadero conflicto con las autoridades eclesiásticas cuando éstas acrecentaron sus actividades económicas o de alguna forma atentaron contra los negocios de sus élites. Ello es lógico, si se tiene en cuenta que las jurisdicciones y competencias de los cabildos y la Iglesia estaban muy delimitadas, además de ser de muy diferente condición. En México, por ejemplo, las divergencias respecto a las actividades económicas de los religiosos se materializaron en la denuncia que en 1602 hizo el procurador general de su cabildo acerca de las muchas casas,

46 Ponce Leiva: Certezas ante la incertidumbre..., págs. 145-147 y 317-329; García Bernal, Manuela Cristina: "D. Rodrigo Flores de Aldana, gobernador de Yucatán (1664-1669)", en Homenaje a Don Antonio Muro Orejón, Sevilla, 1979, vol. I, págs. 134-135; González Muñoz: Cabildos y grupos de poder..., págs. 145-148 y 160-171. Los enfrentamientos entre la Audiencia y el concejo de la capital mexicana por cuestiones de protocolo o injerencias en la actividad capitular aparecen recogidos en Pazos Pazos: El ayuntamiento de la ciudad de México..., págs. 250-254.

47 Laviana Cuetos, María Luisa: "Los intentos de controlar la explotación forestal en Guayaquil: pugna entre el cabildo y el gobierno colonial”, en Peset, José Luis (coord.): Ciencia, vida y espacio en Iberoamérica, Madrid, 1989, vol. II, págs. 397-413. 
haciendas y posesiones que los frailes tenían en la ciudad y, sobre todo, en su propuesta de que los jesuitas no tuvieran "tratos ni granjería en piedra, cal y madera, y en el campo no tuvieran frailes, ni teatinos, por el perjuicio que causan a la república y el mal trato que dan a los indios". ${ }^{48}$ En cambio, el conflicto que se planteó en Yucatán entre 1660 y 1665 fue por las tasas que percibían los franciscanos de los indios y que determinados miembros del concejo de Mérida consideraban excesivas, recomendando por ello que las doctrinas de los franciscanos fuesen entregadas a los clérigos seculares. La respuesta del obispo en favor de los religiosos y de su propia actuación consistió en denunciar los onerosos repartimientos de géneros que el gobernador y los encomenderos hacían a los indios, en los cuales participaban los alcaldes que se habían enfrentado a los franciscanos, justo en un momento en que habían asumido el gobierno provincial por muerte del gobernador. De ahí que el obispo pusiera de relieve que los alcaldes que habían informado al rey en contra de las limosnas "eran encomenderos de pueblos, cercados de parientes, amigos y compadres, porque todos eran iguales y todos encomenderos interesados por igual y se hallaban entonces con el mando superior de la provincia". Es decir, lo que en el fondo se ventilaba era los beneficios económicos que una u otra parte podían conseguir de los indígenas. ${ }^{49}$

La conclusión que se puede extraer de los múltiples aspectos analizados es que los grupos capitulares indianos, aun dentro de su gran diversidad, constituyeron verdaderas élites de poder, tanto en el plano político como en el económico y social. Y, como tales, desarrollaron unas prácticas o mecanismos bastante homogéneos a la hora de afianzar ese poder. Hubo, sin embargo, modos formales e informales en el ejercicio de su poder. El formal o directo provendría del acceso al cabildo, por elección, compra o herencia, mientras que el informal o indirecto se ejercería a través de las redes de parentesco, de influencias o de conexiones económicas que dichas élites lograron establecer. Ambos modos, sin embargo, sirvieron a las oligarquías locales para consolidar e incrementar su riqueza y prestigio, pero sobre todo para conformar un distinguido círculo con identidad propia, capaz de hacer valer su hegemonía en todos los ámbitos de la vida municipal y hasta del gobierno provincial o regional.

48 Pazos Pazos: El ayuntamiento de la ciudad de México..., págs. 262-265 (la cita textual corresponde a la página 263).

49 González Muñoz: Cabildos y grupos de poder..., págs. 181-188 (la cita textual corresponde a la página 185$)$. 